\title{
The nominal price analysis of trading financial assets at fair value
}

\author{
Bayi Guan, Xuejie Wang, Zhanli Shang, Zhongquan Chen \\ Yantai Nanshan University, Yantai, China
}

\begin{abstract}
Recognizing trading financial assets at their fair value facilitates quick transaction and convenient accounting, however, it causes uncertainty in terms of reasonable price, validity of market and involvement of investors. On some levels, the determination of fair value is subjective and artificial to a large extent and lacking in objectivity. Assets recognition seemingly rational based on financial reports does not result in valid inflow of funds or turn trading financial assets into equivalent monetary funds. Conducting an analysis on the nominal price of trading financial assets is a re-visit of the prudence principle of accounting as well as an interpretation of rationality of fair value recognition.

Index Terms - trading financial assets; fair value; recognition; nominal price; rationality

Trading financial assets is purchase in secondary market of financial assets such as shares, bonds and investment funds for the purpose of short-term profits. It is mainly recognized at fair value at the end. As it data in the financial reports of public companies affect share prices, it raises wider public concerns and consequently causes manipulation of recognition of fair value at the end, making 'fair value' less fair and resulting in the nominal price of trading financial assets.
\end{abstract}

\section{Determination of fair value of trading financial assets}

In the secondary market of investment funds, the most outstanding determination of fair value is in call auction and continuous auction of trading financial assets. As ruled by Shanghai Stock Exchange, when traded by auction , 9.15am to 925am is the time for open call auction every trading day, while it is ruled by Shenzhen Stock Exchange, when traded by auction, $9.15 \mathrm{am}$ to $9.25 \mathrm{am}$ and $14.57 \mathrm{pm}$ to $15.00 \mathrm{pm}$ are time for open call auction and close call auction respectively. At this stage, fair value is determined as the realizable maximum volume (quantity). If two maximum volumes exist, the fair value will be determined as the medium price of the two following the principle of price preference and time preference. In this case, buy at higher prices and sell at lower prices are all closed, and buying or selling at the same price is all closed on one side at least. The fair value is determined following the mode of 'Zhou Yu beats Huang Gai', during which process manipulation may exist. Therefore, it falls after strong gains in the first hours of trading because buyers do not accept.

In terms of the determination of the fair value in continuous auction, in both Shanghai and Shenzhen stock exchange markets $9.30 \mathrm{am}$ to $1130 \mathrm{am}$ and $13.00 \mathrm{pm}$ to $15.00 \mathrm{pm}$ every trade date are time for continuous auction, while in Shenzhen Stock Exchange market, $13.00 \mathrm{pm}$ to $14.57 \mathrm{pm}$ is time for continuous auction. During these time periods, fair value is determined by the way of individually consecutive match following below principles: 1. Highest buying price equals to lowest selling price. 2 . If buying price is higher than immediate lowest selling price, fair value is the highest immediate buying price. 3. If selling price is lower than highest immediate buying price, fair value is the highest immediate buying price. When the fair value is determined this way, stock market volatility occurs because market participants do not accept the fair value.

\section{Symptoms of nominal price}

The fair value of trading financial assets to determine if there was a brief manipulated, will inevitably lead to the distortion measurement, there is no market price. The so-called price without the city mainly refers to, although the price seems fair, but did not actively involved among the participants, resulting in a price immeasurable. Following are analysis of the causes.

\section{A. Continuous falls after open}

We are always on the secondary market in securities trading systems time-trend that many trading financial assets are often higher open quickly after diving in intraday trading, making trading financial assets rapidly shrinking. This phenomenon is a standard there is no market price performance, this phenomenon is often in the opening call auction when some makers use their own financial strength and the number of holdings advantages, both to act as buying bid side, and act as selling counterparties to the absolute superiority volume orders of the opening of trading on the fair value of the underlying securities will be determined, to lure other parties while chasing the high of their own selling fast shipping, thus achieving the purpose of short-term profit. Of course, this phenomenon is also affected by other bear news, but the most important is the opening call auction to determine the fair value of the price distortions caused by the irrational investor participation is not high and there is no market price caused instant diving stock market on called "priced immeasurable, potential soon!

\section{B. Wide fluctuation in the middle}

For continuous auction to determine the fair value principle, different investment participants different price psychological expectations, which is different from the socalled recognition of their fair value. Considered undervalued participants will use the principle of "selling price is lower than the highest real-time purchase price, the purchase price in order to determine the highest immediate" determination 
timely price, making it the current fair value; that the participants will be overvalued use principles "of the purchase price is higher than the minimum selling price instant to instant the lowest selling price is determined" to determine promptly the price, making it the current fair value. Both cases will produce different results, the former makes the underlying securities continued to rise, which makes the underlying securities continue to decline, which resulted in the intraday fluctuated. According to different bookmakers Kongpan degree determined for each target price has serious differences, there will be sold (so-called fair value) of a serious departure from, so most participants cannot participate in the sale of the declaration, thus forming intraday fluctuated Under no market price phenomenon. As for the "highest buying price and lowest selling the same," the price determination principle, it is the fair value of short-term stalemate in front of two different price expectations of the presentation of the determination mode, which is the market in a sideways wait behaviour.

\section{Rapid rise when market closes}

Quickly pulled up close is also a market price behaviour of the right to speak, their behaviour in order to fair value of trading financial assets to determine the underlying securities. According to their purpose can be summarized into three different styles: one for arbitrage in late raised the ship; the second is to determine the ideal closing price, raised the ship for the next day ready to do closing; the third is for the future continued to rise while food goods positions. Of the three different styles of behind play a decisive role or behaviour have shareholdings and financial advantages of the participants, their behaviour is to the fair value of trading financial assets is determined, and thus achieve their different motives closing price. No matter what kind of purpose participants are using their own stock of both securities and funds act as counterparties, affect the fair value is determined in a short time, and then a so-called fair value, which is the mouthpiece. Quality of information in this case because it is short before the close of the transaction, so the day's volume is not affected, but it greatly affected the day's closing price, especially in the accounting period of the trading day, it will greatly affect the accounting. This behaviour also results in nominal price of trading financial assets.

\section{Impacts on accounting at the end}

Reasonable or not, whether the cash equivalent of the fair value of trading financial assets identified, have some impact on investors and investors will be accounting, especially for measurement of the accounting period, but will have different degrees of distortion, manipulation report data.

\section{A. Impacts on Balance Sheet}

The fair value of trading financial assets is determined in the final accounting in the financial situation will have an impact. The fair value has been seriously overvalued, because - increase the account "trading financial assets changes in fair value" and inflated profit or assets, thereby affecting the increase in net assets, leading investors in listed companies and asset condition misjudgement blindly follow the trend, leading to investment risks; fair value has been seriously underestimated, because of "trading financial assets - change in fair value" account and reduce profit undervalued assets, thereby affecting the decrease in net assets, leading investors to target listed companies assets status misjudgement and missed investment opportunities. Financial situation or distortion will have a serious impact on investors' and investees' balance sheets.

\section{B. Impacts on Income Statement}

The fair value of trading financial assets will determine the impact at the end of the current period operating results, thereby affecting the income statement. Since the end of each period income statement items of income, gain on change in fair value to add or subtract losses from changes in fair value, which is the fair value of trading financial assets overvalued due to an increase lenders' losses from changes in fair value "account, which led to increase profits, thus affecting the increase in earnings per share, so that investors mistakenly overestimate the profitability of listed companies to generate investment risk; fair undervalued trading financial assets due to increased debit "changes in fair value gains and losses" account, which led to reduce profits, thus reducing the impact of earnings per share, so that investors underestimate the profitability of listed companies, and the risk of losing investment opportunities increase. Whether it is overvalued or undervalued profit profits are so influenced by the quality of information in the income statement.

\section{Impacts on Cash Flow Statement}

Trading fair value of financial assets have no market price situation will directly affect the cash flow statement information. Price without the biggest drawback is that very few market opportunities for trading financial assets at the disposal of the carrying amount of the assets cannot be the equivalent of the current period cash inflows are often lower than the carrying varying degrees of probability trading financial assets is large, greater than or equal to. Due to continuous diving after opening, intraday fluctuated, closing quickly pulled up and so much to determine the fair value of the acts of unfair trading financial assets, resulting in the end of trading financial assets measured at the time of disposal of cash inflows significantly below the carrying amount of its assets and the cash flow statement information leads to distortion, resulting in investment cash flow per share of participants miscarriage of justice arising from different levels of investment risk.

\section{Conclusion}

Effect of measurement at fair value of trading financial assets have no market price for many reasons, but based on the accounting problems caused by human factors, the following three aspects recommendation:

Firstly, for the opening auction phase of opening using the top five largest volumes determine the opening price. The 
fair value of the price it would be more reasonable to determine the balance, avoid large stock funds and securities manipulation open, and avoid opening the diving phenomenon.

Secondly, the Shanghai and Shenzhen have implemented the first three minutes to close auction mode, using the top five largest volume determine the closing price to determine the fair value.

Last but not least, for the measurement of the end of trading financial assets using the average closing price of the five trading days of the measurement. So it can better avoid the fair value of the distortion, can better embody the principle of prudence.
In short, high-speed developments of market economy to accounting provided a broad space, but also increase the difficulty and challenges of accounting, timely accounting and supervision in order to better serve the socialist market economy.

\section{References}

[1] Li. G.B. 2014. Theory of fair value accounting standards in China "carrying", "vacancy" and "covering". Accounting Mothly.

[2] SAC,2012.Securities tradin. Beijing: Chinses Finance Press 2012.

[3] Ministry of finance accounting qualification assessment center. 2007. Intermediate accounting practice. Beijing: Economic Science Press. 